\begin{tabular}{|l|l|l||}
\hline \multicolumn{2}{|c|}{ PublisherInfo } \\
\hline \hline PublisherName & $:$ & BioMed Central \\
\hline \hline PublisherLocation & $:$ & London \\
\hline \hline PublisherImprintName & $:$ & BioMed Central \\
\hline \hline
\end{tabular}

\title{
Resistant sheep get BSE
}

\begin{tabular}{|l|l|l||}
\hline \multicolumn{2}{|c|}{ ArticleInfo } \\
\hline \hline ArticleID & $:$ & 4781 \\
\hline \hline ArticleDOI & $:$ & $10.1186 /$ gb-spotlight-20030530-01 \\
\hline \hline ArticleCitationID & $:$ & spotlight-20030530-01 \\
\hline \hline ArticleSequenceNumber & $:$ & 133 \\
\hline \hline ArticleCategory & $:$ & Research news \\
\hline ArticleFirstPage & $:$ & 1 \\
\hline \hline ArticleLastPage & $:$ & 2 \\
\hline \hline & & RegistrationDate : 2003-5-30 \\
\hline ArticleHistory & $:$ & OnlineDate \\
\hline \hline ArticleCopyright & $:$ & BioMed Central Ltd2003-50 \\
\hline \hline ArticleGrants & $:$ & \\
\hline \hline ArticleContext & $:$ & 130594411 \\
\hline \hline
\end{tabular}




\section{Tudor P Toma}

Email: t.toma@imperial.ac.uk

Resistance to transmissible spongiform encephalopathies (TSEs) in sheep can be influenced by polymorphisms of the gene that encodes prion protein $(\operatorname{Pr} P)$. In vitro conversion experiments showed that VRQ and ARQ alleles of $\operatorname{Pr} P$ are associated with susceptibility to bovine spongiform encephalopathies (BSE), whereas the ARR allele is associated with resistance to the conversion of $\operatorname{PrP}$ to the disease-causing $\mathrm{PrP}^{\mathrm{Sc}}$ form. But in the May 29 Nature, Fiona Houston and colleagues from Institute for Animal Health show that even the sheep with the genotype associated with highest resistance (ARR) can still be infected with BSE by intracerebral inoculation (Nature, 2003, 423:498).

Houston et al. inoculated infected cattle-brain homogenate into the brain of sheep with different $\operatorname{Pr} P$ genotypes and investigated their resistance to transmission of BSE. They observed that VRQ and ARQ sheep developed the disease, and that 3 out of 19 ARR/ARR sheep showed clinical symptoms of BSE. In addition, western-blot analysis of the abnormal protease-resistant fraction of $\operatorname{PrP}\left(\operatorname{PrP}{ }^{\mathrm{Sc}}\right)$ and immunohistochemical labelling of disease-associated PrP in brain sections from the ARR/ARR sheep were consistent with experimental BSE in ARQ/ARQ sheep.

"The susceptibility of ARR/ARR sheep to intracerebral injection with BSE indicates that these animals cannot be regarded as having absolute genetic resistance to TSE infection... Although the relevance of this finding to sheep exposed to natural infection remains to be determined, it may have important implications for disease-eradication strategies," conclude the authors.

\section{References}

1. Sheep and goats: natural and experimental TSEs and factors influencing incidence of disease.

2. Nature, [http://www.nature.com/nature]

3. Institute for Animal Health, [http://www.iah.bbsrc.ac.uk/] 